\title{
Collaborative creativity Supporting teaching and learning on campus
}

W

e have so many questions about the future and not many answers. Earlier in this essay series, Shelley Phipps asks, "What will our mission or core purpose be?" and identifies the key questions with which libraries are grappling. Among the most important questions Phipps raises is, "Can we collaborate, truly?"1 My answer is a resounding, "Yes!"

Librarians need to collaborate creatively with other partners to better support teaching and learning on campus. "Find it, understand it, use it" is not just the information maxim for librarians. Information literacy skills are taught not only by librarians, but by student support services and faculty as well, even though these educators may not be familiar with the term information literacy.

Finding academic quality resources, understanding the perils of plagiarism, creating an MLA-style annotated bibliography, verifying the credentials of an author, respecting the copyright rules for using images and quotations, and experiencing the benefits of browsing the physical stacks and the full-text online databases are being discussed in many venues around campus.

The academic work being done by faculty and students is changing. Students are creating videos as term papers, collaborating on research projects that will take the shape of Web pages, and composing research papers that incorporate images, music, or video files. Student needs are complicated in this fantastic age of information and their support needs can no longer be met by a single academic department or student service.

Library programs are reaching out to other student support offices on campuses.
While traditionally, librarians have sought to collaborate with faculty, we now look to collaborate with others groups, working increasingly with colleagues from academic computing, the writing program, international office, academic skills center, women in science, residential life, athletics, career services, and many others.

\section{Collaborate across campus}

Dartmouth College recently created a new student center for Research, Writing and Information Technology (RWIT). An initiative between the writing program, academic computing, and the library, RWIT provides peer-to-peer support in composition, research, and technology in Baker-Berry Library. ${ }^{2}$ The center, now in its second year and still in development, is a collaboration among three units, each with its own philosophy and own mode of working. Running the peer tutoring center requires constant communication and attention to planning, funding, and assessment by professional staff from each of the three departments. The success of the center depends on the ability of the involved staff to communicate, to solve problems, and to develop and support a shared vision for RWIT.

The idea for RWIT came about when staff from academic computing and the composition center were talking about the need for multimedia composition support for students.

Susan Fliss is director of education and outreach at Dartmouth College Library, e-mail: Susan. Fliss@Dartmouth.Edu

๑) 2005 Susan Fliss 
Simultaneously, the library approached the composition center to discuss the need for composition tutors to be skilled in information literacy practices and to know how to do research using the library. Similar ideas are percolating across academic libraries; these ideas are a natural next step after learning commons.

In addition to the RWIT team, I'm fortunate to work with a group of librarians who can be collaboratively creative. Being creative in a group is difficult to do. Upon hearing a new idea, one's initial impulse is to break it down rather than continue to develop it. It takes time to develop the skills of meeting as a group, brainstorming ideas, letting an idea float and be encouraged, making suggestions (some practical, some wacky), and watching thoughts morph into a workable idea with a very different shape from what was first suggested. With a group the shape is usually more creative and firmly based in solving a problem or meeting a need than if a single person or two had worked on it.

When a new person participates in a brainstorming session, he or she has to learn to control the impulse to immediately critique the idea. This is hard enough to do among librarians who share a common understanding of their role and work, but how is this done with other constituents on campus?

\section{Courage and marketing}

In approaching potential collaborators, there's always the fear that they won't see the value in working with us-we've seen that look on faces across campus before when we've made suggestions. The "look" can surely bring about a tight knot in the pit of one's stomach, but it can mean many things: the other party feels there is not enough time in her schedule to collaborate, or he's tried something like that before and it didn't work, or she doesn't quite understand why the library wants to partner with her group-the library does all right on its own, doesn't it?

Don't assume people from other student support services have been keeping up with the changes in libraries and how librarians work with students and faculty. Do you know what changes have been going on in their areas? We may have to market librarians and libraries to other constituent groups on campus, as we do to new students and faculty.

Investigating new ways of working with faculty is a good approach to take when collaborating with other departments on campus. If we want to increase our partnerships with faculty for the future, we must learn about the teaching techniques and new technologies faculty use in order to be able to work with them in the classroom. In doing so, we are better poised to approach faculty to integrate student development of information literacy skills into the curriculum.

This means devising strategies to become involved with the Center for Teaching on campus, for example. Are librarians welcome to attend their training programs? Can librarians lead a session sponsored by the center on designing assignments to develop research skills? Will librarians attend conferences in the disciplines to keep current in teaching and research trends in the disciplines we liaise with? For that matter, what about attending a conference on teaching and computing, or the Conference on College Composition and Communication, the American Chemical Society, or the American Historical Association annual meetings?

Approaching faculty in your department and asking to have a conversation about their teaching is daunting; they are receptive to hearing about new services and library Web site features, but talking about teaching is another matter entirely. So, ask one or two members from a department to come to talk with librarians about teaching in their discipline and invite them to work with librarians to devise more options for supporting them in their teaching and in student learning. Teaching and learning will go both ways at that meeting.

Librarians also need to identify and make connections with other players who support faculty in their teaching and students in their learning. For example, partner with academic computing to integrate librarian resources and 
librarian participation into course management systems; collaborate with the writing program, academic skills center, and English Department in first-year information literacy or writing intensive courses; work with residential life in devising a role for librarians in activities planned in the residence halls; create a My Librarian program with the international office, athletics department, or graduate studies office.

How will the librarian's role in teaching and learning change in the future? Time will tell, and I can't wait to see! During this transition, the librarian's role will become stronger, firmly accepted, and more integrated into teaching and learning, if we continue to develop collaborative relationships and projects with faculty and with other departments on campus.

\section{Lessons learned}

- First, don't assume anyone knows what librarians do.

- Make contact with potential collaborators and talk about new developments in the library or with library services. In conversation, find the common challenges and-among those challenges - the ones that are also common priorities.
- Who else needs to be in the conversation? Expand to include other groups.

As needs and solutions come about, a group of interested players will emerge. Some will withdraw because the identified project is not a priority, or there is not enough staff or not enough interest among staff. That's okay. Remember to keep them informed of how the group progresses. Later, they will be an ally.

In working with the interested group, the process may well develop bumps along the way because the group will be made up of people coming from different points of view and points of service, and it takes time to develop a shared vision of that collaborative project. Be patient on days when the meetings just don't go well. Give ideas time to gel; it can take several meetings, months, even longer, for ideas to come to fruition.

If you're not sure where the project or idea should go next, consult with students. It's for them, after all. What are they experiencing? What do they need? Better yet, involve students in the conversation from the beginning. Hmm, yes, this is how collaboration should begin-with the students!

(continued on page 407)

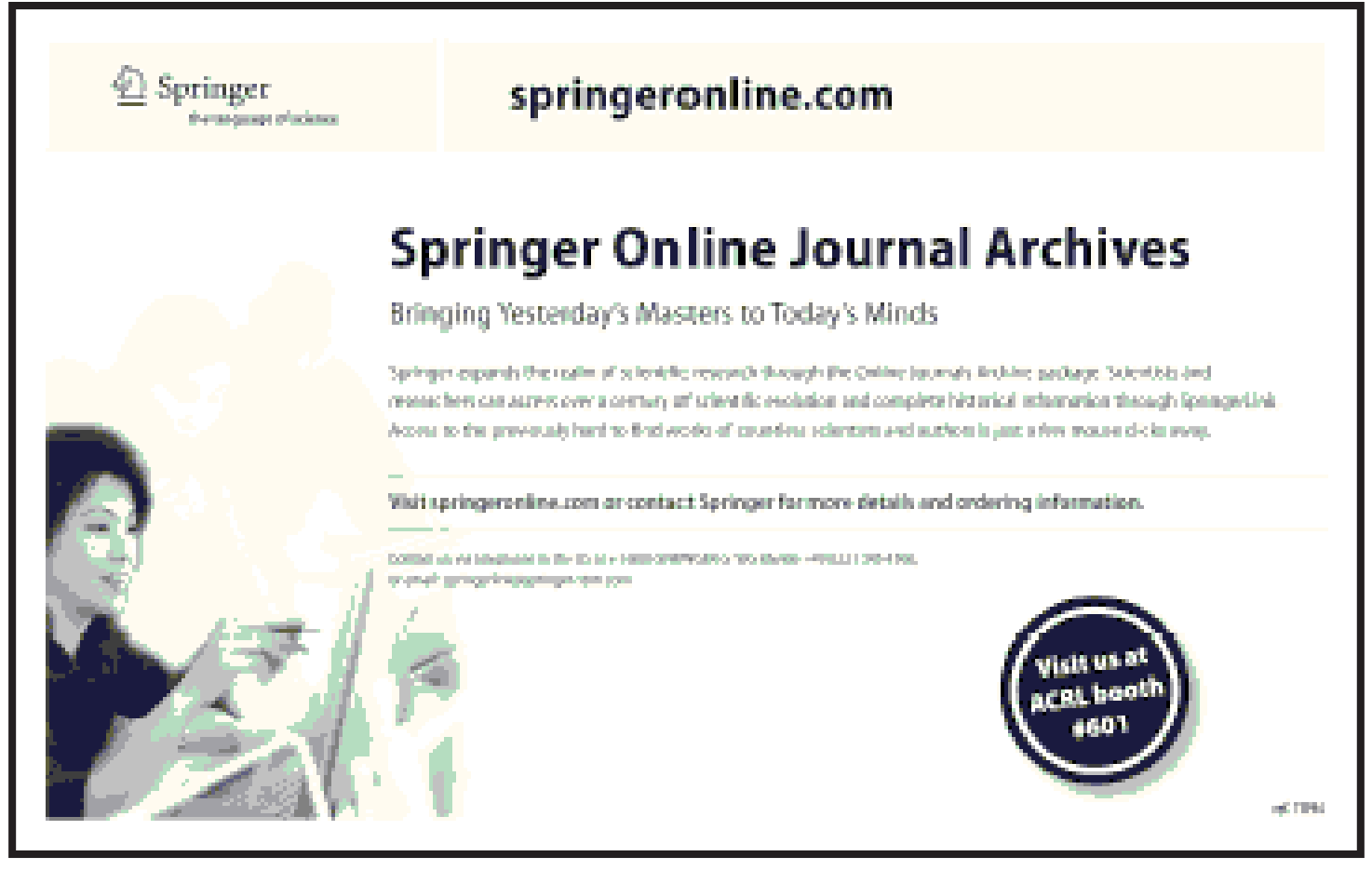


("Collaborative creativity" continued from page 380)

Ruth A. Pagell, in the January issue of this series, ended her article with the advice, "The key is to embrace change as opportunity."

We need to start collaborating creatively now because we're only going to have more "opportunities" in the future.

\section{Notes}

1. Shelley Phipps, "Rafting the rapids," CERL News 66, 2 (February 2005): 116, 117.

2. For more information, consult www. dartmouth.edu/ rwit/.

3. Ruth A. Pagell, "The more things change...: The past as a signpost for the future," CERL News 66, 1 (January 2005) 35. \# 